\title{
Comparison of affective temperament profiles in male patients with chronic obstructive pulmonary disease according to groups
}

\author{
Kronik obstrüktif akciğer hastalı̆̆ı olan erkek hastalarda afektif mizaç \\ profillerinin gruplara göre karşılaştırılması
}

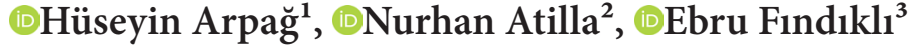 \\ ${ }^{1}$ Batman Medical Park Hospital, Department of Chest Diseases, Batman, Turkey \\ ${ }^{2}$ Kahramanmaraş Sütçü İmam University School of Medicine, Department of Chest Diseases, Kahramanmaraş, Turkey \\ ${ }^{3}$ Kahramanmaraş Sütçü İmam University School of Medicine, Department of Psychiatry, Kahramanmaraş, Turkey
}

Cite this article as/Bu makaleye atıf için: Arpağ H, Atilla N, Fındıklı E. Comparison of affective temperament profiles in male patients with chronic obstructive pulmonary disease according to groups. J Health Sci Med 2020; 3(4): 473-478.

\begin{abstract}
Introduction: The aim of this study was to determine the temperament profiles of male patients with chronic obstructive pulmonary disease (COPD) according to disease groups.

Material and Method: A total of 80 male COPD patients without any additional disease were included in the study. Patients were staged as group A, group B, group C and group D according to 2019 Global Initiative for Chronic Obstructive Lung Disease (GOLD) criteria. The Turkish version of the Temperament Evaluation of Memphis, Pisa, Paris and San Diego Auto (TEMPS-A) and the Hospital Anxiety Depression Questionnaire scales (HADS) were used to determine the dominant affective temperaments.

Results: Totally 80 COPD patients including 20 from each group were recruited into our study. The majority of COPD patients did not have any dominant temperament (n:28). Depressive temperament was found in 18 patients $(22.5 \%)$ as the most common dominant affective temperament, followed by anxious temperament in 10 patients (12.5\%). Anxious temperament was significantly dominant in group A, while there wasn't any significant difference between groups for depressive temperament $(\mathrm{p}=0.034, \mathrm{p}=0.36)$. Cyclothymic and irritable temperaments were found to be more common in group A ( $\mathrm{p}=0.006, \mathrm{p}=0.048)$. According to the HADS, depression scores were significantly higher in group B than in other groups ( $\mathrm{p}=0.03$ ).

Conclusion: Our study demonstrated that there is a negative correlation between COPD severity and incidence of affective temperaments. To cope with the disease better, COPD patients in early stages are in need of psychological support at least patients in advanced stage.
\end{abstract}

Keywords: Affective temperament profiles, chronic obstructive pulmonary disease

\section{ÖZ}

Giriș: Bu çalışmanın amacı, kronik obstrüktif akciğer hastalığı (KOAH) tanısı olan erkek hastaların hastalık gruplarına göre mizaç profillerini araştırmaktır.

Gereç ve Yöntem: Kronik obstrüktif akciğer hastalığı tanısı olup, ek hastalığı olmayan 80 erkek hasta çalışmaya dahil edildi. Hastalar 2019 Global Initiative for Chronic Obstructive Lung Disease (GOLD) kriterlerine göre A grubu, B grubu, C grubu ve D grubu olarak evrelendirildi. Baskın mizacı belirlemek için Memphis, Pisa, Paris ve San Diego Oto Mizaç Değerlendirme (TEMPS-A) Türk versiyonu ve Hastane Anksiyete Depresyon anket ölçeği (HADS) kullanıldı.

Bulgular: Her gruptan 20 olmak üzere toplam 80 KOAH hastası çalışmaya dahil edildi. KOAH hastalarının büyük çoğunluğunda herhangi bir baskın mizaç yoktu (n:28). Depresif mizaç 10 hastada (\%12,5) görülürken, endişeli mizaç en sık baskın mizaç olarak 18 hastada (\%22,5) saptandı. Endişeli mizaç profili grup A’da baskın iken, depresif mizaç için gruplar arasında anlamlı bir fark olmadığı görüldü ( $p=0.034$, $\mathrm{p}=0.36)$. Siklotimik ve irritabl mizaç grup A'da daha sık olarak saptandı $(\mathrm{p}=0.006, \mathrm{p}=0.048)$. HADS ölçeğine göre grup $\mathrm{B}$ hastaları diğer gruplara göre daha depresifti $(\mathrm{p}=0.03)$.

Sonuç: Çalışmamız KOAH şiddeti ve afektif mizaç sıklığı arasında negatif bir korelasyon olduğunu göstermiştir. KOAH hastalarının hastalıkla daha iyi başa çıkabilmeleri için, sadece ileri evrede değil, erken evrelerde de psikolojik desteğe ihtiyacı vardır.

Anahtar Kelimeler: Afektif mizaç profilleri, kronik obstrüktif akciğer hastalığı 


\section{INTRODUCTION}

Chronic obstructive pulmonary disease (COPD) is a respiratory disorder that is characterized by persistent airflow obstruction. Worldwide the most commonly encountered risk factor for COPD is tobacco smoking. Nonsmokers may also develop COPD (1).

In order to COPD development takes many years and is not exactly reversible, these patients may have severe physical limitations and substantial psychosocial trouble. There are various studies investigating the relationship between psychological and emotional distresses and COPD.

The 2019 global initiative for chronic obstructive pulmonary disease (GOLD) guidelines considers symptoms and history of exacerbation rather than the degree of airflow obstruction for classification of COPD (1). At the same time comorbidities as anxiety and depression have been included in to new guideline. It is also possible that other psychological variables, such as personality traits and temperaments may influence the progression of the illness, as well as rehabilitation and treatment achievement. Nevertheless, psychological characteristics and temperaments are not given enough importance in guidelines.

Temperament has been defined as a biologically determined, hereditary core of the personality, being stable and relatively unchangeable throughout life, which determines the basic level of reactivity, mood and energy of given individual (2). It is possible to see it as a feature of personality without affective disorders or a basis of affective disorders, like depression or bipolar disease, throughout life. Five dominant affective temperaments are described: depressive, hyperthymic, cyclothymic, irritable and anxious (3). The temperament characteristics of the patient may influence success in competing with stress and may also affects keeping the disease under control.

The aim of this study is to compare the dominant temperament profiles between groups in Turkish patients with COPD in accordance with the new classification.

\section{MATERIAL AND METHOD}

The study comprised 80 COPD patients aged 45-70 years. In order to form a homogenous group, only male participants were included. Individuals enrolled in study did not have any comorbid disease. Exclusion criteria were based on the inability of the patient to reliably respond to questionnaires in the interview. All of them were recruited from our chest outpatient clinic where they were regularly followed-up and fulfilled the GOLD criteria for the classification of COPD. This study was approved by the university/local human research ethics committee and all procedures performed in studies involving human participants were in accordance with the ethical standards of the institutional and/ or national research committee and with the 1964 Helsinki Declaration and its later amendments or comparable ethical standards. The study was carried out with the permission of Research Ethics Committee of Kahramanmaraş Sütçü İmam University faculty of medicine University faculty of medicine (Permission granted/CAAE number: 2014/30.04, Decision no: 72).

\section{Classification of Patients}

Patients were grouped as A, B, C, D according to 2019 GOLD guideline. Twenty patients from each group, who have been in the same control group for at least one year were enrolled.

Symptom burden is measured by modified Medical Research Council questionnaire (mMRC)

- A=Low symptom burden (mMRC of 0-1) and and low exacerbation rate (0-1/year).

- $\mathrm{B}=$ Higher symptom burden (mMRC of 2 ) and low exacerbation rate (0-1/year).

- $\mathrm{C}=$ Low symptom burden (mMRC of 0-1) and high exacerbation rate (2 or more/year)

- $\mathrm{D}=$ Higher symptom burden (mMRC of 2 ) and high exacerbation rate (2 or more/year)

\section{Questionnaire Scales}

The Turkish version of the Temperament Evaluation of Memphis, Pisa, Paris and San Diego Auto Questionnaire scale (TEMPS-A) was used to determine the dominant affective temperament, and the Hospital Anxiety Depression Scale (HADS) was used also. Each interview took about 15 minutes.

The HADS is a four Likert-type scale identifying the level and intensity variation which developed by Zigmond and Snaith to measure patient anxiety and the risk of depression. Comprises a total of 14 questions and contains anxiety (HADS-A) and depression (HADS-D) subscales. In studies conducted in Turkey for cutting the anxiety subscale score was found $10 / 11$, while the depression subscale was $7 / 8$. Accordingly, these points are considered to be at risk on the field. The scoring of each item in the scale is different. 1, 3, 5, 6, 8, 10, 11 and 13 show a gradually decreasing intensity and $3,2,1,0$ scoring format. On the other hand, the 2nd, 4 th, 7 th, 9 th, 12th, and 14th amendments are scored 0, 1, 2, 3 format.

The Turkish version of TEMPS-A scale was used to determine the dominant affective temperament in the subjects. The validity and reliability of TEMPS-A has been proven in many languages, and in Turkish by Vahip et al. (2). The Turkish version of the scale consists of 99 
items. This scale is a self-report instrument consisting of five subscales. It's 99 constituent items inquire about the subject's whole life about traits along depressive, cyclothymic, hyperthymic, irritable and anxious lines. Individuals answer 'yes'or 'no'when considering their life experience. Cutoff scores to determine the dominant temperament are 13 for depressive mood (18 items), 18 for cyclothymic (19 items), 20 for hyperthymic (20 items), 13 for irritable (18 items) and 18 for anxious (24 items). It is possible to have more than one dominant affective temperament $(4,5)$.

\section{Description of Temperaments}

1. Hyperthymic Temperament: described in those individuals who display this type of affective temperament as usually cheerful and overoptimistic, warm and extroverted, as having high energy levels, overinvolved in several activities, uninhibited, sensation seeking and with promiscuous tendency, and their length of sleep is commonly short (6).

2. Depressive Temperament: The depressive (or dysthymic) temperament has been classically described in those subjects who are usually unable to see the lighter side of things, are self-denying, have low energy levels and are critical, negativistic and highly introverted, don't like changes, meeting new people or exploring new situations $(7,8)$.

3. Cyclothymic Temperament: The basic trait of the cyclothymic temperament is a pattern of alternation between hypomanic or irritable, and depressive subclinical moods, cognitions, and behaviors. Emil Kraepelin (9) has described this temperament as the alternation of the previous two temperaments described above (hyperthymic and depressive).

4. Irritable Temperament: The irritable temperament was classically defined by Emil Kraepelin (9) as the lifelong combination, at the same time, of both hyperthymic and depressive temperaments. The irritable temperament is characterized by depressive mood with periods of irritability, high emotional implication in different activities, in the sense that they become very difficult to afford, impulsive, with inner tension and dysphoric restlessness, insatisfaction, unhappiness and bitter disposition, often hypercritical and complaining to others, obtrusiveness, habitually moody and bite disposition, tendency to brood, intrusive and untimely (11).

5. Anxious Temperament: It is characterized as the continuous presence of harm avoidance, dependency, shyness, inability to relax, insecurity, uncontrollable worrying about mundane matters, hypervigilance, tension and gastrointestinal distress, and irritability (10).

\section{Statistical Analysis}

In this study SPSS 11.5 (SPSS Inc., Chicago , IL, USA) statistical analysis was performed. Significance levels were evaluated in $\mathrm{p} \leq 0,05$. Descriptive statistics data reported by percentage or mean $\pm \mathrm{SD}$. McNemar test was used to assess the compliance categorically. The chi-square test was used in order to compare categorical variables.

\section{RESULTS}

The mean age was $60.7 \pm 8.13$. From 80 COPD patients who were recruited into our study, depressive temperament was found in 18 patients $(22.5 \%)$ and was the most common dominant affective temperament, followed by anxious temperament in 10 patients (12.5\%). Cyclothymic temperament was found in 4 patients, hyperthymic in 4 and irritable temperament was found in 4 patients also. The majority of COPD patients (n:22) did not have any dominant temperament (27.5\%). (Table 1). According to HADS, anxiety (n:44) was seen more than depression (n:26). (Table 2).

\begin{tabular}{|c|c|c|c|c|c|c|}
\hline \multirow[b]{2}{*}{ Temperament } & \multicolumn{6}{|c|}{ COPD groups } \\
\hline & & $\mathbf{A}$ & B & $\mathrm{C}$ & D & p \\
\hline \multirow{2}{*}{ Depressive } & Yes & 6 & 4 & 6 & 2 & \multirow{2}{*}{0,36} \\
\hline & No & 14 & 16 & 14 & 18 & \\
\hline \multirow{2}{*}{ Cyclothymic } & Yes & 0 & 4 & 0 & 0 & \multirow{2}{*}{$0,006^{*}$} \\
\hline & No & 16 & 20 & 20 & 20 & \\
\hline \multirow{2}{*}{ Irritable } & Yes & 4 & 0 & 2 & 0 & \multirow{2}{*}{$0,048^{*}$} \\
\hline & No & 16 & 20 & 18 & 20 & \\
\hline \multirow{2}{*}{ Hyperthymic } & Yes & 2 & 2 & 0 & 0 & \multirow{2}{*}{0,24} \\
\hline & No & 18 & 18 & 20 & 20 & \\
\hline \multirow{2}{*}{ Anxious } & Yes & 6 & 2 & 2 & 0 & \multirow{2}{*}{$0,034^{*}$} \\
\hline & No & 14 & 18 & 18 & 20 & \\
\hline \multirow{2}{*}{$\begin{array}{l}\text { Lack of } \\
\text { temperament }\end{array}$} & Yes & 8 & 12 & 14 & 18 & \multirow{2}{*}{$0,010^{*}$} \\
\hline & No & 12 & 8 & 6 & 2 & \\
\hline
\end{tabular}

\begin{tabular}{|c|c|c|c|c|c|}
\hline \multicolumn{6}{|c|}{ COPD groups } \\
\hline HADS & A & B & C & D & $\mathbf{p}$ \\
\hline HAD-A & $9,8 \pm 3,7$ & $9,6 \pm 3,4$ & $11 \pm 4,8$ & $10,6 \pm 5,2$ & 0,92 \\
\hline HAD-D & $5,5 \pm 4,1$ & $10,6 \pm 5,2$ & $7,6 \pm 2$ & $7,9 \pm 4,2$ & $0,03^{\star}$ \\
\hline
\end{tabular}

When we considered the results according to groups, the number of depressive temperament in groups $\mathrm{A}$, $\mathrm{B}, \mathrm{C}, \mathrm{D}$ was $6,4,6,2$ respectively $(\mathrm{p}=0.36)$. There was no statistically significant differences between groups in terms of depression. Anxious temperament seen in groups $\mathrm{A}, \mathrm{B}, \mathrm{C}, \mathrm{D}$ was respectively $6,2,2,0$. That result was statistically significant $(p=0.034)$. Fifty-two patient 
hasn't got any temperament $(\mathrm{p}=0.01)$. Cyclothymic temperament was seen in 4 patients and all of them were from group $B$. That result was statistically significant $(\mathrm{p}=0.006)$. Irritable temperament was seen in 4 patient in group $\mathrm{A}$, in 2 patient in group $\mathrm{C}$ and none in groups $\mathrm{B}$ and D. That result was statistically significant also $(\mathrm{p}=0.048)$. Hyperthymic temperament was seen in 2 patients in group $A$ and 2 patients in group $B$. This results were not statistically significant $(\mathrm{p}=0.24)$. Lack of temperament was seen most in group D and C $(\mathrm{p}=0.01)$ (Table 1).

According to HADS, anxiety was seen most in group C. But the result was not statistically significant $(p=0.92)$. Depression was seen significantly higher in group $B$ $(\mathrm{p}=0.03)$. (Table 2).

COPD groups are also compared separately as: $\mathrm{A}$ and $\mathrm{B}$, $\mathrm{A}$ and $\mathrm{C}, \mathrm{A}$ and $\mathrm{D}, \mathrm{B}$ and $\mathrm{C}, \mathrm{D}$ and $\mathrm{B}, \mathrm{C}$ and $\mathrm{D}$. There is a statistically significant difference between groups $\mathrm{A}$ and $\mathrm{B}$ according to cyclothymic, irritable, and the mixed temperaments $(p=0.03)$, between groups $A$ and $C$ according to cyclothymic temperament $(p=0.03)$, between groups $\mathrm{A}$ and $\mathrm{D}$ according to cyclothymic, irritable and mixed temperaments $(p=0.03)$ and between groups $\mathrm{B}$ and $\mathrm{D}$ according to lack of temperament $(\mathrm{p}=0.03)$. (Table 3).

\section{Table 3. Comparison of COPD subgroups}

\begin{tabular}{|c|c|c|c|c|c|c|}
\hline & A-B & A-C & A-D & B-C & B-D & C-D \\
\hline Depression & 0.47 & 1.00 & 0.11 & 0.47 & 0.38 & 0.11 \\
\hline Cyclothymic & ${ }^{\star} 0.03$ & ${ }^{\star} 0.03$ & ${ }^{\star} 0.03$ & 1.00 & 1.00 & 1.00 \\
\hline Irritability & ${ }^{\star} 0.03$ & 0.38 & ${ }^{\star} 0.03$ & 0.15 & 1.00 & 0.15 \\
\hline Hypertimic & 1.00 & 0.15 & 0.15 & 0.15 & 0.15 & 1.00 \\
\hline Anxious & 0.11 & 0.11 & ${ }^{*} 0.009$ & 1.00 & 0.15 & 0.15 \\
\hline $\begin{array}{l}\text { Lack of } \\
\text { temperament }\end{array}$ & 0.21 & 0.06 & ${ }^{*} 0.001$ & 0.51 & ${ }^{\star} 0.03$ & 0.11 \\
\hline $\begin{array}{l}\text { Mixed } \\
\text { temperament }\end{array}$ & ${ }^{\star} 0.03$ & 0.38 & ${ }^{\star} 0.03$ & 0.15 & 0.15 & 1.00 \\
\hline Depression & 0.47 & 1.00 & 0.11 & 0.47 & 0.38 & 0.11 \\
\hline
\end{tabular}

\section{DISCUSSION}

Our study is the first one using the TEMPS-A and HADS questionnaire to compare temperament characteristics of COPD patients between groups. There are several studies related to temperament and character profiles of personality in patients with COPD. However there isn't any that using TEMPS-A and HADS between COPD groups according to new guideline.

Temperament is affected by genetic and environmental factors (12). COPD is also known to be affected by genetic, socioeconomic and environment factors too (13). Before starting to study we thought that affective temperaments especially anxiety and depression would be more frequent in the advanced stages of COPD patients than in the early stages. But the statistical results showed the opposite. In our study, we found that depression was the most common temperament in whole COPD patients. However there was no statistically significant difference in incidence between the groups according to TEMPS. Depression scores found to be significantly higher in group $\mathrm{B}$ according to HADS.

In general practice, there seems to be a relationship between depression and the severity of the COPD, with $25 \%$ of patients with severe COPD also having depression, $19.6 \%$ of those with mild COPD, and $17.5 \%$ of those in the control group (14). In a study of Turkey, the prevalence of depression in COPD male patients was $29.6 \%$ (15). A meta-analysis from England identified a prevalence of major depression in patients with moderate-to-severe COPD in an out-patient setting of $40 \%$ (16). Some studies reported a significant increase in the prevalence of depression, but others reported no significant differences between COPD patients and controls (17). In our study, the prevalence of depression was $22.5 \%$, and this result is similar to other studies.

In our study anxious temperament was seen most in group A. Because of they are worrier, anxious patients applies to clinician even if they have minor complaint. Perhaps a bit of anxiety is needed, especially for early diagnosis of COPD. However, respiratory distress develops in very long time period, patients (especially does not care about the health) usually refer to clinician in the advanced stages of the disease. It can be the reason for anxiety was determined less in advanced stages of COPD.

The symptom of dyspnea, which is a major complaint of COPD patients, is accepted to be a potent stimulus for anxiety (18). Inability to perform daily activities or expected social roles may also lead them to feel anxious. In our country, Celik et al. (19) found the prevalence of anxiety to be about $44 \%$ in COPD patients. In the USA, unadjusted prevalence of anxiety was higher among those with COPD (15\%) than in controls (6\%) (20). In our study, the incidence of anxiety was $12.5 \%$ generally, and according to groups it was seen most in group A patients. According to HADS we didn't find any significant difference between groups. These results are similar to those of other studies.

Cyclothymic, hyperthymic and irritable temperaments were found to be less common in patients with COPD. Hyperthymic temperament was seen in only 4 patient and this was not statistically significant. Irritable temperament was seen in 6 patients, 4 from group A and 2 from group C. Cyclothymic temperament was seen in 4 patients including all in group B. So irritable and cyclothymic temperament was more frequent in the early 
stages of the disease. Only a few studies investigated the role of personality in COPD. In one study, COPD patients were found to be more neurotic than healthy controls (21). The basic trait of the cyclothymic temperament is a pattern of alternation between hypomanic or irritable, and depressive subclinical moods, cognitions, and behaviors (9). Compared to the advanced stages of COPD, respiratory function and blood oxygen level is less impaired in early stages, subclinical depressive or manic mood disorder that may have resulted in the emergence of mild depression or hypomania. The irritable temperament was classically defined by Emil Kraepelin (9) as the lifelong combination, at the same time, of both hyperthymic and depressive temperaments. The irritable temperament is characterized by depressive mood with periods of irritability, high emotional implication in different activities, in the sense that they become very difficult to afford, impulsivity (11). Because of significant physical and psychosocial impairment secondary to severe dyspnea in advanced COPD, life expectancy decreases. The prevalence of cognitive impairment in patients with COPD was found to be associated with the severity of the disease (22). This may explain why irritability, mood changes like aggressiveness seen less in the advanced stages of COPD.

Similar to these results there was a positive correlation between disease severity and lack of temperament. It is possible that patients become unresponsive or too weak to give response due to perseverance in coping with the disease is reduced.

\section{Study Limitations}

This is a single-center study with a relatively small study population, both of which limit the power of our research findings. There was no control group in our study as we compared the groups among themselves and we also excluded the patients with chronic additional diseases, and therefore, our results cannot be extrapolated to all COPD patients. Further studies are required to clarify this subject.

\section{CONCLUSION}

Our study showed that in early stage of COPD, dominant affective temperaments are seen much more than advanced stages of disease. Psychological support should be given to COPD patients even though they were in early stages.

\section{ETHICAL DECLARATIONS}

Ethics Committee Approval: The study was carried out with the permission of Research Ethics Committee of Kahramanmaraş Sütçü İmam University faculty of medicine University faculty of medicine (Permission granted/CAAE number: 2014/30.04, Decision no: 72).

Informed Consent: All patients signed the free and informed consent form.
Referee Evaluation Process: Externally peer-reviewed. Conflict of Interest Statement: The authors have no conflicts of interest to declare.

Financial Disclosure: The authors declared that this study has received no financial support.

Author Contributions: All of the authors declare that they have all participated in the design, execution, and analysis of the paper, and that they have approved the final version.

\section{REFERENCES}

1. Global strategy for the diagnosis, management and prevention of chronic obstructive lung disease. GINA-2019.

2. Strelau J. Psychologia temperamentu. Warszawa: Wydawnictwo Naukowe PWN 2009.

3. Vahip S, Kesebir S, Alkan M, Yazici O, Akiskal KK, Akiskal HS. Affective temperaments in clinically-well subjects in Turkey: initial psychometric data on the TEMPS-A. J Affect Disord 2005; 85: 113-25.

4. Akiskal HS, Akiskal KK. TEMPS: Temperament evaluation of Memphis, Pisa, Paris and San Diego. J Affect Disord 2005; 85: 1-2.

5. Kurt E, Karacan I, Ozaras N, Alatas G. Affective temperament in stroke patients. J Acta Neuropsychiatrica 2008; 20: 295-9.

6. Akiskal KK, Akiskal HS. The theoretical underpinnings of affective temperaments: implications for evolutionary foundations of bipolar disorder and human nature. J Affect Disord 2005; 85: 231-9.

7. Akiskal HS, Akiskal KK. Cyclothymic, hyperthymic and depressive temperaments as subaffective variants of mood disorders. In: Tasman A, Riba MB, Eds. Annual Review, vol II. Washington, D.C.: American Psychiatric Press 1992; pp. 43-62.

8. Possl J, von Zerssen D. A case history analysis of the "manic type" and the "melancholic type" of premorbid personality in affectively ill patients. Eur Arch Psychiatry Clin Neurosci 1990; 23: 347-55.

9. Kraepelin E. Manic-depressive illness and paranoia. Edinburgh: Livingstone 1921.

10. Akiskal HS. Toward a definition of generalized anxiety disorder as an anxious temperament type. Acta Psychiatr Scand Suppl 1998; 393: 66-73.

11. Akiskal HS, Mallya G. Criteria for the "soft" bipolar spectrum: treatment implications. Psychopharmacol Bulletin 1987; 23: 68-73.

12. Gillespiea NA, Cloningerb CR, Heathc AC, Martina NG. The genetic and environmental relationship between Cloninger's dimensions of temperament and character. J Pers Individ Diff 2003; 35: 1931-46.

13. Hynninen KM, Breitve MH, Wiborg AB, Pallesen S, Nordhus IH. Psychological characteristics of patients with chronic obstructive pulmonary disease: a review. J Psychosom Res 2005; 59: 429-43.

14. Van Manen JG, Bindels PJ, Dekker FW, Jzermans CI, van der Zee J S, Schade E. Risk of depression in patients with chronic obstructive pulmonary disease and its determinants. Thorax 2002; 57: 412-6.

15. Kömürcüoğlu B, Balığlu M, Öztuna I, Büyükşirin M, Işık E, Kunter P. KOAH'lı erkek olgularda depresyon (Depression among male COPD patients). J Toraks 2000; 2910: 31-4.

16. Yohannes AM, Connolly MJ. Do antidepressants work in patients with chronic obstructive pulmonary disease with comorbid depression? Expert Rev. J Respir Med 2011; 5: 727-9.

17. Van Ede L, Yzermans CJ, Brouwer HJ. Prevalence of depression in patients with chronic obstructive pulmonary disease: a systematic review. J Thorax 1999; 54: 688-92. 
18. Hill K, Geist R, Goldstein RS, Lacasse Y. Anxiety and depression in end-stage COPD. Eur Respir J 2008; 31: 667-77.

19. Çelik P, Esen A, Akın M. Kronik obstrüktif akciğer hastalığı olgularında depresyon. (Depression in COPD patients). J Solunum Hastalıkları 1998; 9: 25-32.

20. Eisner MD, Blanc PD, Yelin EH, et al. Influence of anxiety on health outcomes in COPD. J Thorax 2010; 65: 229-34.

21. Rutter BM. Some psychological concomitants of chronic bronchitis. Psychol Med 1977; 7: 459-64.

22. Thakur N, Blanc PD, Julian LJ, et al. COPD and cognitive impairment: the role of hypoxemia and oxygen therapy. Int $\mathrm{J}$ Chron Obstruct Pulmon Dis 2010; 5: 263-9. 